\title{
OPTIMIZATION OF MOLECULAR DETECTION FOR Vibrio cholerae and PATHOGENIC Escherichia coli USING MULTIPLEX PCR
}

Diana Elizabeth Waturangi ${ }^{l}$, Jason Petrus ${ }^{I}$, Rico Kosasih ${ }^{I}$, Felicia Roseline Sujonoputri ${ }^{l}$

Address (es):

${ }^{1}$ Atma Jaya Catholic University of Indonesia, Faculty of Biotechnology, Department of Biotechnology, Jl. Jendral Sudirman No. 51, Jakarta 12930.

*Corresponding author: diana.waturangi@atmajaya.ac.id

\section{ABSTRACT}

Vibrio cholerae and pathogenic Escherichia coli were considered as main causative agent foodborne diseases especially in many developing countries, such as Indonesia. Thereby, rapid detection of these pathogenic bacteria is necessary to treat food-borne related diseases causing by these bacteria. In this case, multiplex PCR allows multiple genes amplification in one reaction thereby enable to perform rapid detection of these pathogenic bacteria. The objective of this study is to optimize uniplex and multiples PCR of $V$. cholerae and pathogenic E. coli detection and determine the sensitivity and specificity of this assays. We used various virulence genes for each pathogenic bacterium as markers for uniplex and multiplex PCR detection. Based on this research, the optimum results of $V$. cholerae and pathogenic E. coli were obtained with a primer concentration of $16 \mu \mathrm{M}$ for $c t x A$ and $o m p U, 30 \mu \mathrm{M}$ for ace, and $50 \mu \mathrm{M}$ for zot, and toxR; $2 \mu \mathrm{M}$ for $e l t$ and $5 \mu \mathrm{M}$ for stx, respectively. Finally, based on the standardization method by ISO/TS 20836 these assays had $0 \%$ false positive, $0 \%$ false negative, $100 \%$ specificity, and $100 \%$ sensitivity; $0 \%$ false positive, $4 \%$ false negative, $100 \%$ specificity, and $96 \%$ sensitivity for $V$. cholerae and pathogenic $E$. coli respectively. The optimized method was qualified to be used as a molecular detection for $V$. cholerae as well as EHEC and ETEC detection according to ISO/TS 20836 (2017) from drinking water samples.

Keywords: Rapid detection, PCR multiplex, Foodborne diseases, Vibrio cholerae, Pathogenic Escherichia coli

\section{INTRODUCTION}

Contamination of food and drinks has been one of the main concerns in many developing countries, such as Indonesia causing various kinds of diseases one of which is diarrheal. Some of the main causative bacteria which cause this contamination are $V$. cholerae and pathogenic E. coli. These bacteria can spread through faecal and oral causing foodborne diseases, which potentially leading to high level of morbidity and mortality (Gomes et al., 2016).

The pathogenicity of these bacteria comes from the expression of cluster of virulence genes. For example, expression of $c t x A$ and ompU genes in $V$. cholerae leads to production of cholerae toxin and colonization of these bacteria in the small intestine, respectively (Wibbenmeyer et al., 2002). Whereas in E. coli, it is known that most of pathogenic $E$. coli strain are harmless, but some serotypes are pathogen, such as EHEC and ETEC which produce shiga toxin and heat-labile enterotoxin, respectively (Kaper et al., 2004).

In this case, conventional method consists of the usage of selective media, microscopic examination, and biochemistry assay were still used to identify these pathogenic bacteria. However, this method is not reliable and quick enough to identify these bacteria in case of an outbreak happens. Advances in molecular techniques has led to a shift from conventional methods to molecular method, which are more sensitive, specific, and more reproducible. PCR based detection test is fast and sensitive technique to identify pathogenic bacteria by detecting virulence genes which presence in bacteria. However, regular PCR is only capable of detecting single gene in one PCR reaction but multiplex PCR provides the possibility of amplifying several genes in one PCR reaction (Kim et al. 2015). Therefore, it is important to develop rapid molecular detection of these pathogenic bacteria and analyze their sensitivity and specificity.

\section{MATERIAL AND METHODS}

\section{Pathogenic Bacteria Cultivation}

In this research, we used several of pathogenic bacteria namely $V$. cholerae $\mathrm{C} 43$ and E. coli ATCC 25922 which provided by BPOM; EHEC and ETEC which acquired from US Namru. The cryo-preservated bacteria were defrosted. Then, the bacteria were streaked onto LA, except for $V$. cholerae which were streaked onto $\mathrm{LA}+2 \%(\mathrm{w} / \mathrm{v}) \mathrm{NaCl}$. In order to confirm the bacteria then each bacterium was grown in their selective media. For example, $V$. cholerae and pathogenic $E$. coli were grown in TCBS and EMB, respectively. Subsequently, bacteria which showed the right morphology then streaked onto their growth media for further assay.

Table 1 Primer sequences and melting temperatures

\begin{tabular}{|c|c|c|c|c|c|c|}
\hline Bacteria & Genes & & Size & $\mathrm{TM}$ & $\begin{array}{l}\text { Concentration } \\
(\mu \mathrm{M})\end{array}$ & Sequences \\
\hline \multirow{10}{*}{ V. cholerae } & \multirow[t]{2}{*}{$\operatorname{ctxA}$} & $\mathrm{F}$ & 564 & 65.9 & 50 & CGGGCAGATTCTAGACCTCCTG \\
\hline & & $\mathrm{R}$ & & 64.7 & 50 & CGATGATCTTGGAGCATTCCCAC \\
\hline & \multirow[t]{2}{*}{ tox $R$} & $\mathrm{~F}$ & 779 & 62.1 & 50 & CCTTCGATCCCCTAAGCAATAC \\
\hline & & $\mathrm{R}$ & & 62.1 & 50 & AGGGTTAGCAACGATGCGTAAG \\
\hline & \multirow[t]{2}{*}{$z o t$} & $\mathrm{~F}$ & 947 & 62.1 & 50 & TCGCTTAACGATGGCGCGTTTT \\
\hline & & $\mathrm{R}$ & & 62.1 & 50 & AACCCCGTTTCACTTCTACCCA \\
\hline & \multirow{2}{*}{ ace } & $\mathrm{F}$ & 316 & 66.3 & 50 & TAAGGATGTGCTTATGATGGACACCC \\
\hline & & $\mathrm{R}$ & & 60.9 & 50 & CGTGATGAATAAAGATACTCATAGG \\
\hline & \multirow[t]{2}{*}{ ompU } & $\mathrm{F}$ & 869 & 62.1 & 50 & ACGCTGACGGAATCAACCAAG \\
\hline & & $\mathrm{R}$ & & 62.1 & 50 & GCGGAAGTTGGTTGAAGTAG \\
\hline \multirow{4}{*}{$\begin{array}{l}\text { ETEC and } \\
\text { EHEC }\end{array}$} & \multirow[b]{2}{*}{ stx } & $\mathrm{F}$ & & 51.6 & 50 & GAG CGA AAT AAT TTA TAT GTG \\
\hline & & $\mathrm{R}$ & 518 & 52.3 & 50 & TGA TGA TGG CAA TTC AGT AT \\
\hline & \multirow{2}{*}{ elt } & $\mathrm{F}$ & & 58.4 & 50 & TCT CTA TGT GCA TAC GGA GC \\
\hline & & $\mathrm{R}$ & 322 & 55.2 & 50 & CCA TAC TGA TTG CCG CAAT \\
\hline
\end{tabular}

(Singh et al., 2002; Toma et al., 2003).

\section{Genomic DNA Extraction}

The isolates were cultured on LB for overnight at $37^{\circ} \mathrm{C}$. The extraction of genomic DNA was performed by using boiling method (Dalmasso et al., 2009).
Firstly, $1 \mathrm{~mL}$ of broth culture was centrifuged at $12000 \mathrm{x} \mathrm{g}$ for $5 \mathrm{mins}$. Then the pellet was resuspended in $1 \mathrm{~mL}$ of $\mathrm{NaCl}(0.85 \% \mathrm{w} / \mathrm{v})$, boiled for $5 \mathrm{mins}$, and centrifuged again. The supernatant was stored at $-20^{\circ} \mathrm{C}$ for further use. Quantity, 
quality, and concentration of the extracted DNA were analyzed using Nanodrop instrument and gel electrophoresis.

\section{Uniplex PCR}

All primer pairs (Tab 1) were tested in uniplex PCR at the estimated optimal annealing temperature to confirm correct amplification of the desired genes. Each primer pair was tested on uniplex PCR assay to ensure primer amplification ability and also confirming primer melting temperatures (Sint et al., 2012). Mixture of the reaction and PCR condition was shown (Tab 2 and Tab 3). After PCR reaction, the amplification products were separated in $2.5 \%(\mathrm{w} / \mathrm{v})$ agarose gel electrophoresis at $75 \mathrm{~V}$ for 95 minutes and visualized using GelDoc with $\mathrm{EtBr}$ dye.

Table 2 PCR mixture and volume for uniplex reaction

\begin{tabular}{lcc}
\hline \multirow{2}{*}{ Mixture } & V. cholerae & ETEC and EHEC \\
& \multicolumn{2}{c}{ Volume $(\mu \mathrm{L})$} \\
\hline Go Taq Green Master Mix PCR & 12.5 & 12.5 \\
Primer F & 1 & 1 \\
Primer R & 1 & 1 \\
DNA template & $1.25(50 \mathrm{ng} / \mu \mathrm{L})$ & $2.5(50 \mathrm{ng} / \mu \mathrm{L})$ \\
NFW & 9.25 & 8 \\
\hline
\end{tabular}

Table 3 PCR condition for uniplex reaction

\begin{tabular}{|c|c|c|c|c|}
\hline \multirow[b]{2}{*}{ Phase } & \multicolumn{2}{|c|}{ V. cholerae } & \multicolumn{2}{|c|}{ ETEC and EHEC } \\
\hline & $\begin{array}{c}\text { Temperature } \\
\left({ }^{\circ} \mathrm{C}\right)\end{array}$ & Time & $\begin{array}{c}\text { Temperature } \\
\left({ }^{\circ} \mathrm{C}\right)\end{array}$ & Time \\
\hline $\begin{array}{l}\text { Pre- } \\
\text { denaturation }\end{array}$ & 95 & 5 minutes & 95 & 5 minutes \\
\hline Denaturation & 95 & 1 minute & 95 & 1 minute \\
\hline Annealing & 58 & $90 \mathrm{~s}$ & 52 & 1 minute \\
\hline Elongation & 72 & $90 \mathrm{~s}$ & 72 & 1 minute \\
\hline Post elongation & 72 & 10 minutes & 72 & 10 minutes \\
\hline Hold & 4 & $\infty$ & 4 & $\infty$ \\
\hline Cycle: & \multicolumn{2}{|c|}{30} & \multicolumn{2}{|c|}{30} \\
\hline
\end{tabular}

(Singh et al., 2002; Toma et al., 2003).

\section{Multiplex PCR}

PCR amplification of the target DNA was carried out in a thermal cycler. The bacterial cell lysate was used for the template DNA to multiplex PCR using virulence and regulatory genes as their primers (Tab 1). The mixture of PCR and PCR condition was shown (Tab 4 and Tab 5). Subsequently, the amplification products were separated in $2.5 \%$ agarose gel electrophoresis at $75 \mathrm{~V}$ for 90 minutes and visualized with GelDoc using EtBr dye.

Table 4 PCR mixture and volume for multiplex reaction

\begin{tabular}{|c|c|c|}
\hline \multirow{2}{*}{ Mixture } & V. cholerae & ETEC and EHEC \\
\hline & \multicolumn{2}{|c|}{ Volume $(\mu \mathrm{L})$} \\
\hline Go Taq Green Master Mix PCR & 25 & 12.5 \\
\hline Primer $\mathrm{F}$ & $2(30 \mu \mathrm{M})$ & $1(\mathrm{pmol} / \mu \mathrm{L})$ \\
\hline Primer R & $2(30 \mu \mathrm{M})$ & $1(\mathrm{pmol} / \mu \mathrm{L})$ \\
\hline DNA template & $2.5(50 \mathrm{ng} / \mu \mathrm{L})$ & $2.5(50 \mathrm{ng} / \mu \mathrm{L})$ \\
\hline NFW & 8.5 & 8 \\
\hline
\end{tabular}

Table 5 PCR condition for multiplex reaction

\begin{tabular}{lccccc}
\hline Phase & \multicolumn{2}{c}{ V. cholerae } & & \multicolumn{2}{c}{ ETEC and EHEC } \\
& $\begin{array}{c}\text { Temperature } \\
\left({ }^{\circ} \mathrm{C}\right)\end{array}$ & Time & $\begin{array}{c}\text { Temperature } \\
\left({ }^{\circ} \mathrm{C}\right)\end{array}$ & Time \\
\hline Pre- & 95 & 5 minutes & 95 & 5 minutes \\
denaturation & 95 & 1 minute & 95 & 1 minute \\
Denaturation & 58 & $90 \mathrm{~s}$ & 52 & 1 minute \\
Annealing & 72 & $90 \mathrm{~s}$ & 72 & 1 minute \\
Elongation & 72 & 10 minutes & 72 & 10 minutes \\
Post elongation & 4 & $\infty$ & 4 & $\infty$ \\
Hold & & 30 & & & 30 \\
Cycle: & & & & & \\
\hline
\end{tabular}

(Singh et al., 2002; Toma et al., 2003).

\section{Optimization of Primer Concentration for Multiplex PCR Method}

Each primer pair concentrations in the reaction mix have to be adjusted to optimize reaction. In this research, we used $50 \mathrm{ng} / \mu \mathrm{L}$ of standardized amounts of the DNA templates. By equaling the number of template molecules available for amplification, primer efficiencies can be determined by changing the concentration of each primer pair individually. Primer concentrations were adjusted stepwise by decreasing those pairs that show relatively strong band, and increasing the pair that produced weak band (Sint et al., 2012).

\section{Sensitivity and Specificity Evaluation}

The sensitivity of the primes was tested with serial of dilution of the $V$. cholerae and E. coli (EHEC and ETEC) genomics, which was serially diluted from $10 \mathrm{ng}$; $5 \mathrm{ng} ; 1 \mathrm{ng} ; 0.5 \mathrm{ng} ; 0.25 \mathrm{ng}$ and $10 \mathrm{ng} ; 5 \mathrm{ng} ; 2 \mathrm{ng} ; 1 \mathrm{ng} ; 0.5 \mathrm{ng} ; 0.1 \mathrm{ng}$, respectively. Limit of detection was determined with the lowest DNA concentration that gives clear bands (Waturangi, et al., 2015). Specifically, for $V$. cholerae specificity evaluation was performed in order to confirm whether primer pairs amplify only with the targeted bacteria and do not cross-react with DNA from other species. This test was performed by testing the primers with genomic DNA samples from V. cholerae, pathogenic E. coli, S. typhi, and V. vulnificus.

\section{Specificity, Sensitivity, False Positive, and False Negative Assay}

DNA from pathogenic bacteria were tested and amplified using procedure according to ISO/TS 20836, the acceptance limit for specificity and sensitivity is $\geq 70 \%$, and $\leq 5 \%$ for false positive and false negative were listed (Tab 6 and Tab $\overline{7})$.

Table 6 Specificity, sensitivity, false positive, and false negative assay

\begin{tabular}{lccc}
\hline Bacteria & Repetitions & $\begin{array}{c}\text { DNA concentration } \\
(50 \mathrm{ng})\end{array}$ & Description \\
\hline Positive control & 10 & $1: 5 ; 1: 10 ; 1: 15 ; 1: 20 ;$ & 50 positives \\
$\begin{array}{l}\text { Negative } \\
\text { control }\end{array}$ & 5 & $1: 5 ; 1: 10 ; 1: 15 ; 1: 20 ;$ & 25 negatives \\
$\begin{array}{l}\text { Without } \\
\text { bacteria }\end{array}$ & 15 & - & 15 negatives \\
\hline
\end{tabular}

Screening of Virulence Gene from Genomic DNA Isolated from Beverage Sample

Drinking water was used as samples. Artificial contamination was done to contaminate the samples with the bacteria. Each pathogenic bacterium $(V$. cholerae, ETEC, and EHEC) were cultured in LB medium for overnight at $37^{\circ} \mathrm{C}$ using orbital shaker incubator at $120 \mathrm{rpm}$. Then, $5 \mathrm{~mL}$ of drinking water samples were inoculated with $1 \mathrm{~mL}(0.5 \mathrm{McFarland})$ of the bacteria suspension for artificial contamination purpose (Waturangi, et al., 2015). Subsequently, the samples were incubated using orbital shaker for 24 hours at $120 \mathrm{rpm}$ in three different temperatures $\left(28^{\circ} \mathrm{C}, 4^{\circ} \mathrm{C}\right.$, and $\left.-20^{\circ} \mathrm{C}\right)$.

In this study we used two kinds of approach, which were growing the bacteria and isolate the genomic DNA (indirect method), then DNA from the samples was directly extracted (direct method). After artificial contamination, mineral water sample was streaked onto TCBS or EMB agar and incubated overnight at $37^{\circ} \mathrm{C}$. The positive colonies were streaked to LA $\left(37^{\circ} \mathrm{C}\right.$, overnight) and then cultured in $\mathrm{LB}$ medium at $37^{\circ} \mathrm{C}, 120 \mathrm{rpm}$ overnight. Afterwards, $1 \mathrm{~mL}$ of the suspension was centrifuged at $7513 \mathrm{x} \mathrm{g}$ for two minutes.

Following centrifugation, supernatant was discarded and DNA was extracted from the pellet using Wizard $®$ Genomic DNA Purification Kit (Promega) based on manufacturer's guidelines for indirect method. At the same time, without growing the bacteria, mineral water samples that were artificially contaminated were resumed for genomic DNA extraction using Wizard ${ }^{\circledR}$ Genomic DNA Purification Kit (Promega) based on manufacturer's guidelines for direct method. The extracted genomic DNA from bacterial colonies as well as genomic DNA extracted directly from the samples were continued for multiplex PCR detection. PCR was employed with the same primer concentration and PCR condition as the previous step. 
The PCR condition is the same as the uniplex and multiplex method. The amplification products were separated in $2.5 \%$ agarose gel electrophoresis at 75 $\mathrm{V}$ for 90 minutes and visualized with GelDoc using EtBr dye.

Table 7 Sensitivity and specificity of optimized multiplex PCR

\begin{tabular}{lccc}
\hline \multirow{2}{*}{ Response } & \multicolumn{3}{c}{ PCR results } \\
& + & - & \\
\hline Positive 50 & $\mathrm{A}$ & $\mathrm{B}$ & $\mathrm{A}+\mathrm{B}$ \\
Negative 40 & $\mathrm{C}$ & $\mathrm{D}$ & $\mathrm{C}+\mathrm{D}$ \\
& $\mathrm{A}+\mathrm{C}$ & $\mathrm{B}+\mathrm{D}$ & $\mathrm{N}$ \\
\hline
\end{tabular}

$\mathrm{A}=$ total positive presumptive confirmed positive, $\mathrm{B}=$ total negative presumptive confirmed positive, $\mathrm{C}=$ total presumptive positive confirmed negative, $\mathrm{D}=$ total negative presumptive confirmed negative, $\mathrm{N}=$ total test

Sensitivity: $a /(a+b) \times 100 \%$

Specificity: $d /(c+d) \times 100 \%$

False positive: $c /(c+d) \times 100 \%$; False negative: $b /(a+b) \times 100 \%$.

\section{RESULTS AND DISCUSSION}

\section{Uniplex PCR}

From the uniplex test, we found that DNA sequence amplification using all pathogenic bacteria genome showed all of the virulence genes tested amplicons. For example, the DNA sequence amplification of $V$. cholerae genome showed ctxA, ompU, zot, toxR, and ace amplicons (Fig 1), which sized 596 bp, 869 bp, $947 \mathrm{bp}$, and $316 \mathrm{bp}$, respectively. In addition, the DNA sequence amplification of ETEC and EHEC genome also showed elt (Fig 2) amplicons, respectively, which sized $322 \mathrm{bp}$ and $518 \mathrm{bp}$, respectively. Therefore, all of the primers tested can be used for multiplex PCR analysis.

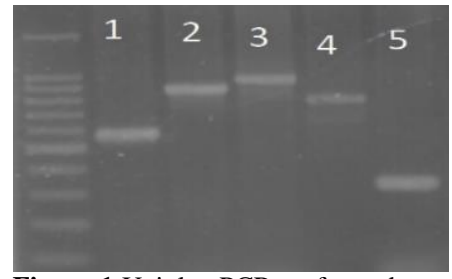

Figure 1 Uniplex PCR performed on $V$. cholerae, which showed ctxA (1), ompU (2), zot (3), toxR (4), and ace (5) amplicons.

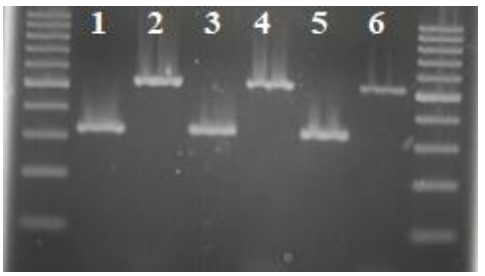

Figure 2 Uniplex PCR performed on EHEC and ETEC, which showed elt (1, 3 , 5) and stx $(2,4,6)$ amplicons, respectively.

\section{Multiplex PCR}

Multiplex PCR was carried out by simultaneous addition of all primer pairs in the same reaction mixture. Optimum results were obtained with primer concentration of $16 \mu \mathrm{M}$ for $c t x A$ and ompU, $30 \mu \mathrm{M}$ for ace, $50 \mu \mathrm{M}$ for $z o t$, and toxR, $2 \mu \mathrm{M}$ for elt, and $5 \mu \mathrm{M}$ for stx (Fig 3 and Fig 4). This primer mix resulted in an even amplification of all fragments when primers of all targets mixed equally.

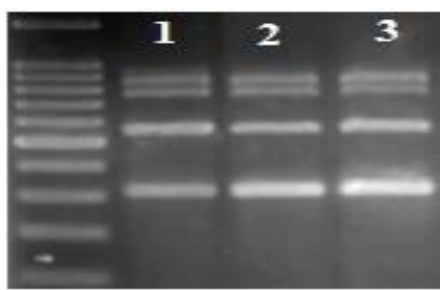

Figure 3 Multiplex PCR performed on $V$. cholerae with three repetitions (1-3).

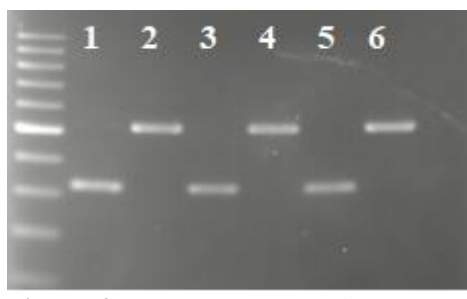

Figure 4 Multiplex PCR performed on ETEC (1, 3, and 5) and $\operatorname{EHEC~(2,~4,~}$ and 6) with three repetitions.
Figure 5 Multiplex PCR sensitivity evaluation was performed on $V$. cholerae with serial of delution of DNA template (1-5). primers produced too strong band. It might happen due to the difference between the amplification product size of all the primers. The possibility of DNA sequence to be amplified was higher if the sequence product was smaller, conversely the possibility was lower if the product was larger.

\section{Sensitivity and Specificity Evaluation}

The sensitivity of assay was performed by observing the lowest DNA concentration could be detected. We found that with the improved primer concentration, the lowest of genomic DNA of $V$. cholerae, ETEC, and EHEC which could be detected was $0.25,1$, and 2 ng, respectively (Fig 5 and Fig 6). In addition, specificity evaluation was performed on $V$. cholerae genome. We found that no amplified product was seen with other non- $V$. cholerae bacterial strains using this multiplex PCR (Fig 7).
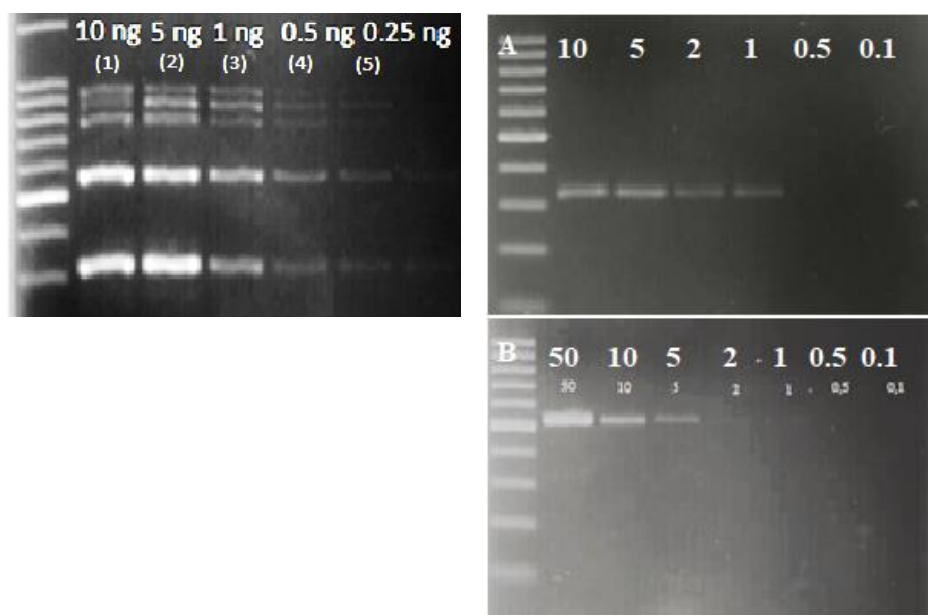

Figure 6 Multiplex PCR sensitivity evaluation was performed on (A) ETEC and (B) EHEC with sereal of delution of DNA template.
The optimization of the multiplex PCR method was done by optimizing all of the primers concentration until the optimum concentrations were acquired, which was $16 \mu \mathrm{M}$ for $c t x A$ and $o m p U, 30 \mu \mathrm{M}$ for ace, $50 \mu \mathrm{M}$ for zot, and toxR in $V$. cholerae and $2 \mu \mathrm{M}$ for elt, and $5 \mu \mathrm{M}$ for stx in ETEC and EHEC, respectively. Below the optimal concentration, all of the primers could not produce a clear band, consistently. Conversely, more than the optimal concentration all of the

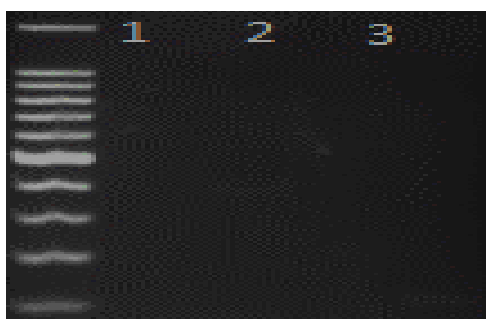

Figure 7 Multiplex PCR specificity assay of (1) Salmonella typhi, (2) E. coli, and (3) Vibrio vulnificus.

\section{Specificity, Sensitivity, False Positive, and False Negative Assay}

The result of specificity, sensitivity, false positive, and false negative assay were shown (Tab 8 and Tab 9). Then, from calculation of the data with formula acquired from ISO/TS 20836, Polymerase chain reaction for the detection of food-borne pathogens, it can be concluded that the $V$. cholerae optimized method had $0 \%$ false positive, $0 \%$ false negative, $100 \%$ specificity, and $100 \%$ sensitivity. While ETEC and EHEC optimized method had $0 \%$ false positive, $4 \%$ false negative, $100 \%$ specificity, and $96 \%$ sensitivity. 
Table 8 The result of $V$. cholerae specificity, sensitivity, false positive, and false negative assay

\begin{tabular}{lccc}
\hline & Control & PCR results \\
\hline Positive & V. cholerae & 50 & - \\
Negative & E. coli WT & 0 & 0 \\
& S. typhi & 0 & 40 \\
& V. vulnificus & 0 & 25 \\
& Without bacteria & 0 & 25 \\
\hline
\end{tabular}

Table 9 The result of ETEC and EHEC specificity, sensitivity, false positive, and false negative assay

\begin{tabular}{lccc}
\hline & Control & \multicolumn{2}{c}{ PCR results } \\
& & + & - \\
\hline Positive & ETEC & 48 & 2 \\
& EHEC & 48 & 2 \\
Negative & E. coli WT & 0 & 25 \\
& V. cholerae & 0 & 25 \\
& Without bacteria & 0 & 15 \\
\hline
\end{tabular}

The sensitivity of the $V$. cholerae optimized multiplex assay proved to be high, as little as $0.25 \mathrm{ng} / \mu \mathrm{L}$ of DNA was sufficient to produce clear bands. In addition, we also found that the sensitivity of ETEC and EHEC optimized multiplex assay proved to be high, as little as $1 \mathrm{ng} / \mu \mathrm{L}$ and $2 \mathrm{ng} / \mu \mathrm{L}$, respectively. Previous study conducted by Mehrabadi et al. (2012) which used three sets of primers $c t x A$, tcpA, and ompW stated that it was possible to detect even at lower numbers, down to between $8.5-85 \mathrm{pg}$ of genomic DNA. Significant sensitivity difference might be resulted from complex formation and competition between primers, therefore the more set of primer used, the more primer competition will happen (Pimenta et al., 2008).

To confirm the specificity of the multiplex assay, we performed specificity evaluation on $V$. cholerae. No amplified product was seen with other non- $V$. cholerae bacterial strains using this multiplex PCR, this result indicates the high specificity of selected primers only specific to $V$. cholerae. Mehrabadi et al. (2012) have tested $c t x A$, tсpA, and отрW gene to Shigella dysenteriae, Aeromonas hydrophila, no amplification product was detected. However, the other study reported that $V$. mimicus might present ompU and toxR genes. This might result a cross reaction when both $V$. cholerae and $V$. mimicus present in the sample, although $V$. mimicus lack the core of the cholerae toxin element ctx $A$ (Singh et al., 2002).

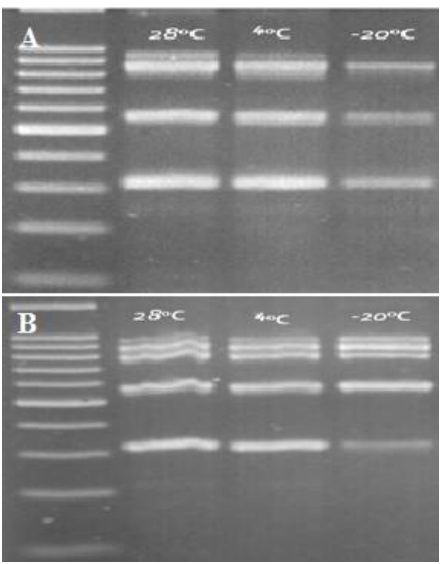

Figure 8 Multiplex PCR of $V$. cholerae (A) direct method and (B) indirect method with three temperatures $28^{\circ} \mathrm{C}(1), 4^{\circ} \mathrm{C}(2)$, and $20^{\circ}(3)$.

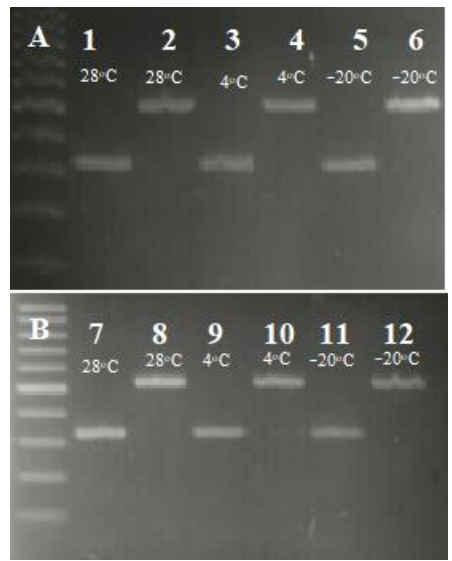

Figure 9 Multiplex PCR of ETEC and EHEC (A) direct method (B) indirect method with three temperatures $28^{\circ} \mathrm{C}$ (1), $4^{\circ} \mathrm{C}(2)$, and $-20^{\circ}(3)$. Lane $1,3,5$, 7, 9, 11 (ETEC) and 2, 4, 6, 8, 10, 12 (EHEC).

\section{Screening of Virulence Gene from Genomic DNA Isolated from Beverage Sample}

With the optimized condition, the multiplex PCR was performed to detect contamination on mineral water sample using artificial contamination. Results showed that all genes tested were amplified and give no significant difference between direct or indirect method (Fig 8 and Fig 9). These assays were also able to detect contamination of pathogenic bacteria in all incubation temperature $\left(28^{\circ} \mathrm{C}, 4^{\circ} \mathrm{C}\right.$, and $\left.-20^{\circ} \mathrm{C}\right)$.

Artificial contamination was performed to analyze the capability of the assay to detect the contamination of pathogenic bacteria tested directly from the sample. The result showed that there was no significant difference between direct and indirect method. Pathogenic bacteria detection method in general normally used bacterial cultivation for selection and enrichment before going into the detection step. However, in outbreak cases that caused by pathogenic bacteria, immediate detection is needed to give the rapid treatment to the patients.

The direct test was meant to see if the optimized method can be used straight to the contaminated water without growing the bacteria in advanced. Therefore, this assay was considered to be important to produce rapid diagnosis, where time is an important factor (Rashid et al., 2017). In addition, based on the result we can also detect all of the pathogenic bacteria tested in all given temperature condition (room, refrigerator, and freezer), which is most common food and water storage placement. In this case, several bacteria such as $V$. cholerae could enter into a viable but non-culturable state in response to unfavorable temperature conditions. When this happens, cultural identification method cannot detect $V$. cholerae contamination in sample (Fernández-Delgado et al., 2015). Since the PCR does not distinguish among viable and dead bacterial cells, this method can be used to even detect all $V$. cholerae contamination in mineral water sample.

Finally, to validate improved assay, we tested this assay using ISO/TS 20836:2017, Polymerase chain reaction for the detection of food-borne pathogens. We found that $V$. cholerae optimized methods had $0 \%$ false positive, $0 \%$ false negative, $100 \%$ specificity, and $100 \%$ sensitivity. While ETEC and EHEC optimized method had $0 \%$ false positive, $4 \%$ false negative, $100 \%$ specificity, and $96 \%$ sensitivity. Therefore, all of the optimized methods have met the requirement for PCR detection of food-borne pathogen according to ISO/TS 20836 limits, where acceptance limits for specificity and sensitivity are $\geq$ $70 \%$, and $\leq 5 \%$ for false positive and false negative.

\section{CONCLUSION}

In this research, several virulence genes primers were used to detect all pathogenic bacteria tested, using optimized multiplex PCR. This assay is able to detect $V$. cholerae which has $c t x A$, ompU, zot, toxR, and ace genes up to $0.25 \mathrm{ng}$ genomic DNA. In addition, this assay is also able to detect ETEC and EHEC which has elt and stx genes up to $1 \mathrm{ng} 2 \mathrm{ng}$, respectively. Based on the method standardization by ISO/TS 20836 these optimized methods are considered acceptable to detect food-borne pathogen tested.

Acknowledgements: The authors are grateful for all the support and everyone who have contributed in this study. We also would like to thank BPOM and US Namru who provided several of pathogenic bacteria tested.

Funding: This research was funded by Atma Jaya Catholic University of Indonesia 2017-2018

Conflict of Interest: The authors declare that they have no conflict of interest.

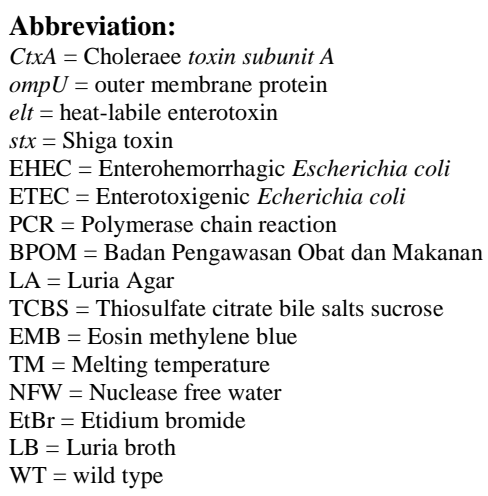

\section{Abbreviation:}

CtxA $=$ Choleraee toxin subunit $A$ Shiga toxin

EHEC $=$ Enterohemorrhagic Escherichia coli Echerichia coli

LA = Luria Agar

$\mathrm{EMB}=$ Eosin methylene blue

$\mathrm{NFW}=$ Nuclease free water

$=$ Etidium bromide

$\mathrm{WT}=$ wild type 


\section{REFERENCES}

Dalmasso, A., La Neve, F., Suffredini, E., Croci, L., Serracca, L., Bottero, M. T., Civera, T. (2009). Development of a PCR assay targeting the rpoA gene for the screening of Vibrio genus. Food Anal Methods. 2, 317-324. http://dx.doi.org/10.1007/S12161-009-9089-9

Fernández-Delgado, M., García-Amado, M. A., Contreras, M., Incani, R. N., Chirinos, H., Rojas, H., SuÁrez, P. (2015). Survival, induction and resuscitation of Vibrio choleraee from the viable but non-culturable state in the Southern Caribbean Sea. Rev. Inst. Med. Trop. Sao Paulo. 57(1), 21-26. http://dx.doi.org/10.1590/S0036-46652015000100003

Gomes, T. A. T., Elias, W. P., Scaletsky, I. C. A., Guth, B. E. C., Rodrigues, J. F., Piazza, R. M. F., Ferreira, C. S., Martinez, M. B. (2016). Medical microbiology diarrheagenic Escherichia coli. Brazilian Journal of Microbiology. 47(1), 3-30. http://dx.doi.org/10.1016/j.bjm.2016.10.015

Kaper, J. B., Nataro, J. P., Mobley, H. L. T. (2004). Pathogenic Escherichia coli. Nat. Rev. Microbiol. 2, 123-140. http://dx.doi.org/10.1038/nrmicro818

Kim, H. J., Ryu, J. O., Lee, S.Y., Kim, E. S., Kim, H.Y. (2015). Multiplex PCR for detection of the Vibrio genus and five pathogenic Vibrio species with primer sets designed using comparative genomics. BMC Microbiol. 15, 239. http://dx.doi.org/10.1186/s12866-015-0577-3

Mehrabadi, J. F., Morsali, P., Nejad, H. R., Fooladi, A. A. I. (2012). Detection of toxigenic Vibrio choleraee with new multiplex PCR. J. Infect. Public Health. 5, 263-267. http://dx.doi.org/10.1016/j.jiph.2012.02.004

Pimenta, F. P., Hirata, R., Rosa, A. C. P., Milagres, L. G., Mattos-Guaraldi, A. L. (2008). A multiplex PCR assay for simultaneous detection of Corynebacterium diphtheriae and differentiation between non-toxigenic and toxigenic isolates. $J$. Med. Microbiol. 57, 1438-1439. http://dx.doi.org/10.1099/jmm.0.2008/000414-0 Rashid, R. B., Ferdous, J., Tulsiani, S., Jensen, P. K. M., Begum, A. (2017). Development and validation of a novel real-time assay for the detection and quantification of Vibrio cholerae. Front. Public Health. 5, 1-12. http://dx.doi.org/10.3389/fpubh.2017.00109

Singh, D.V., Isac, S. R., Colwell, R. R. (2002). Development of a hexaplex PCR assay for rapid detection of virulence and regulatory genes in Vibrio cholerae and Vibrio mimicus. J. Clin. Microbiol. 40, 4321-4324. http://dx.doi.org/10.1128/JCM.40.11.4321-4324.2002

Sint, D., Raso, L., Traugott, M. (2012). Advances in multiplex PCR: Balancing primer efficiencies and improving detection success. Methods Ecol Evol. 3, 898905. http://dx.doi.org/10.1111/j.2041-210X.2012.00215.x

Toma, C., Lu, Y., Higa, N., Nakasone, N., Chinen, I., Baschkier, A., Rivas, M., Iwanaga, M. (2003). Multiplex PCR assay for identification of human hiarrheagenic Escherichia coli. J. Clin. Microbiol. 41, 2669-2671. http://dx.doi.org/10.1128/JCM.41.6.2669-2671.2003

Waturangi, D. E., Amadeus, S., Kelvianto, Y. E. (2015). Survival of enteroaggregative Escherichia coli and Vibrio cholerae in frozen and chilled foods. Journal of Infection in Developing Country. 9(8), 837-843. http://dx.doi.org/10.3855/jidc.6626

Wibbenmeyer, J. A., Provenzano, D., Candice, F., Klose, K. E., Delcour, A. H., Landry, C. F. (2002). Vibrio cholerae ompU and ompT porins are differentially affected by bile. Infection and Immunity. 70, 121-126. http://dx.doi.org/10.1128/IAI.70.1.121-126.2002 